\title{
Dyskurs edukacyjny, weredykcja i pedagogie - od konstelacji związków dyskursu i edukacji do aleturgicznej analizy praktyki edukacyjnej
}

\section{KEYWORDS}

educational discourse, discursive pedagogics, pedagogy, alethurgy, confession, Foucault

\begin{abstract}
Ostrowicka Helena, Dyskurs edukacyjny, weredykcja i pedagogie - od konstelacji związków dyskursu i edukacji do aleturgicznej analizy praktyki edukacyjnej [The educational discourse, veredictions and pedagogies - from the constellations of the relations between discourse and education to the alethurgic analysis of the educational practice]. Kultura - Społeczeństwo - Edukacja nr 2(12) 2017, Poznań 2017, pp. 153-172, Adam Mickiewicz University Press. ISSN 23000422. DOI 10.14746/kse.2017.12.7.
\end{abstract}

\begin{abstract}
The article consists of two major parts. Part one is devoted to the reconstruction of the relationships between the domain of discourse and the domain of education in the semantic field of the term "educational discourse". Based on the analysis of two types of sources (empirical research and the lexicon of contemporary pedagogics), a constellation of functional, thematic, genre and ontological links is shown. In the second part of the article, a reflection on the last of the approach is developed. Referring to Foucault's lectures at the Collège de France in 1979-1980 period, the potential of the category of alethurgy and confession as research instruments of pedagogy and discursive practice is shown.
\end{abstract}

Tytuł niniejszego tekstu w sposób syntetyczny przedstawia jego zawartość. Zasadnicza część rozważań poświęcona jest problemowi związków pomiędzy domeną dyskursu i domeną edukacji, osadzonych w polu semantycznym pojęcia „dyskurs edukacyjny”. Podjęta analiza zmierza do uchwycenia owych związków w formie konstelacji rozumianej jako typologia, zakładająca niehierarchiczny 
układ wyodrębnionych relacji, których zakresy wzajemnie się przenikają i uzupełniają (por. Witosz, 2005; Szczepankowska, 2016). Wychodząc od analizy pól semantycznych pojęcia "dyskurs edukacyjny”, wskazuję również na te znaczenia, w których atrybucja „edukacyjności” dyskursu wytwarzać może zbędne redundancje. W odniesieniu do tego przypadku proponuję, aby dla opisu i analizy dyskursu, który ex definitione jest uznany za praktykę edukacyjną, spożytkować kategorię pedagogii. Pozostając w optyce ontologicznego związku dyskursu i edukacji, w drugiej części artykułu sięgam do wykładów Michela Foucaulta w Collège de France z lat 1979-1980 (Foucault, 2014) i ukazuję potencjał kategorii aleturgii oraz wyznania jako narzędzi badania pedagogii.

Przedstawiana w tym miejscu refleksja nad znaczeniami i zmiennymi ujęciami definicyjnymi pojęcia „dyskurs edukacyjny” wpisuje się w zamysł dyskursywnego (nomen omen) postrzegania przedmiotu badań pedagogicznych. Pedagodzy posługują się terminami „dyskurs” i „dyskurs edukacyjny”, by określić problemy pedagogiczne i opisać, wyjaśnić oraz zinterpretować edukacyjne zjawiska $\mathrm{w}$ ich niejednorodnych i zróżnicowanych aspektach. Dostrzegany i badawczo eksplorowany jest zarówno dyskursywny charakter praktyki edukacyjnej, jak i dyskursywność pedagogiki jako dyscypliny oraz dziedziny wiedzy (Ostrowicka, 2015b). Co istotne, pedagogika dyskursywna nie tylko nieustannie konstruuje przedmiot swoich badań, ale także osadza go „w perspektywie dotychczasowych znaczeń, które poszczególnym przejawom rzeczywistości nadali uczestnicy wspólnoty badaczy w obrębie tej dyscypliny" (Nowak-Dziemianowicz, 2011: 315). Na tym tle uwrażliwienie na dyskursywny charakter pedagogiki wiążę z potrzebą relatywizacji pojęcia dyskursu do kategorii już dobrze zadomowionych w języku pedagogiki (co nie znaczy, że oczywistych i jednoznacznych), to jest do pojęć edukacji i pedagogii. Pedagogika dyskursywna to pedagogika ze swoistym językowym „wyczuleniem”, a może nawet „uczuleniem” na kontekst procesów definiowania i konstruowania znaczeń, a tym samym kontekst konstruowania jej tożsamości. Dla doprecyzowania powyższych stwierdzeń istotne jest dodatkowe wyjaśnienie, iż pojęcia dyskursywności używam, aby zaznaczyć, że zarówno nauka, jak i naukowe kategorie są przedmiotami dyskursu, a więc ich znaczenia zależą od historycznie uwarunkowanych systemów norm i reguł formacji wiedzy (por. Foucault, 1977). Tym samym sygnalizuję już we wstępie własne preferencje teoretyczne i filozoficzne, które konfrontację z odmiennymi stanowiskami uznają za potrzebną i konieczną.

Zarówno dyskurs, jak i edukacja to terminy szerokie i wieloznaczne, zatem ich połączenie w wyrażeniu „dyskurs edukacyjny” niesie różne znaczenia. Świadomość wielu ujęć relacji dyskursu i edukacji skłania do refleksji na dwóch pozio- 
mach: leksykalnym/językowym i teoretyczno-metodologicznym. Najpierw podjęty zostanie namysł nad terminologią. W analizie leksykalnej uwzględniłam dwa źródła:

- doniesienia z badań empirycznych, w których tytule wykorzystano wyrażenie „dyskurs edukacyjny”,

- definicje leksykalne, ukazujące różne typy związku dyskursu i edukacji w wyjaśnieniach pojęcia „dyskurs edukacyjny”.

W drugiej części artykułu ukazany zostanie teoretyczno-metodologiczny potencjał konkretyzacji dyskursywnych badań nad edukacją z zastosowaniem pojęcia pedagogii. Proponowane tu podejście nie oznacza prostego sprowadzenia wszystkich zjawisk edukacyjnych do praktyk dyskursywnych, lecz ukazuje ich związek poprzez analogię. Dzięki tej analogii z powodzeniem można angażować narzędzia dostarczane przez teorie dyskursu i metody analizy języka w badaniach nad szeroko rozumianą edukacją (por. Howarth, 2008).

Zacznę od refleksji nad zastosowaniem wyrażenia „dyskurs edukacyjny” w badaniach empirycznych. Ustalenia pochodzące z moich wcześniejszych badań (Ostrowicka, 2014; 2015b) staną się punktem wyjścia do sproblematyzowania sensu pojęcia dyskursu edukacyjnego w optyce postfoucaultowskiej ${ }^{1}$.

\section{Dyskurs edukacyjny - analiza leksykalna}

Badawczy potencjał kategorii dyskursu tkwi z jednej strony w eksplanacyjno-deskryptywnej mocy teorii dyskursu, z drugiej zaś w atrakcyjności metod i narzędzi jego analizy. $\mathrm{Na}$ ich podstawie konceptualizuje się związki dyskursu i edukacji, czego wyrazem są między innymi rozmaite znaczenia przypisywane terminom: dyskurs edukacyjny, dyskurs pedagogiczny, dyskurs pedagogizacyjny czy edukacjonalizacja dyskursu. Teoretyczna niewspółmierność i zróżnicowanie doprowadziły do rozwoju interdyscyplinarnych badań empirycznych, które łączy wspólna nazwa, lecz dzielą zarówno przesłanki teoretyczne, jak i zastosowane metody.

Prześledzenie publikacji wyników badań empirycznych, które w tytule opatrzone zostały terminem „dyskurs edukacyjny”, ukazuje obraz niezwykle zróżnicowany - badania te różnią się zarówno przedmiotem, specyfiką tematyczną, orientacją teoretyczną, jak i kategoriami analitycznymi oraz zastosowanymi metodami badawczy-

\footnotetext{
${ }^{1}$ W związku z tym, że tekst ten jest kontynuacją i rozwinięciem moich wcześniejszych badań (Ostrowicka, 2014; 2015b), w miejscach, w których było to konieczne dla jasności wywodu, zawiera on niezbędne powtórzenia.
} 
mi (Ostrowicka, 2015b). Już na podstawie przeprowadzonej selektywnej analizy możemy zauważyć, że pluralizm w tym obszarze jest pochodną wieloznaczności dwóch konstytutywnych pojęć: dyskursu i edukacji. W badaniach empirycznych, których autorzy posługują się terminem „dyskurs edukacyjny”, przedmiotem zainteresowań jest komunikacja codzienna, spontaniczna (na przykład opiekunek z dziećmi, Milewski, 1996) oraz zinstytucjonalizowana. W tym drugim przypadku mieszczą się analizy podręczników szkolnych (np. Nasalska, 2004; Rypel, 2012; Popow, 2015a; 2015b), sformalizowanych wypowiedzi podczas lekcji szkolnej (np. Żydek-Bednarczuk, Zeler 1994) i wypowiedzi naukowych: wykładów i tekstów konferencyjnych (np. Ożdżyński, 1996; Seredyńska, 2013). Materiału empirycznego w badaniach nad dyskursem edukacyjnym dostarczają teksty pisane, wypowiedzi ustne, a także dane wizualne (w tym także ikoniczne) - razem lub osobno. Co ciekawe, źródłem danych są również wybory respondentów w teście (np. Koszyk, Machowska, 1996), a zatem nie tylko formy językowe. Badacze dyskursu edukacyjnego wykorzystują kategorie analityczne pochodzące z językoznawstwa (takie jak retoryka, strategia dyskursywna, metafora, topos, morfologia, składnia) i z nauk społecznych (np. działanie strategiczne, działanie instrumentalne, zewnętrzne i wewnętrzne warunki działania, wartości autoteliczne, wartości instrumentalne, praktyki społeczne). Dane zbierane są nie tylko za pomocą typowego przeszukiwania dokumentów, dzięki metodom etnograficznym, takim jak obserwacja, ale także przy zastosowaniu technik ilościowych typu test i ankieta. Badania nad dyskursem edukacyjnym osadzone są w teoretycznej perspektywie różnych odmian lingwistyki: w psycholingwistyce, socjolingwistyce, etnolingwistyce, pedolingwistyce, lingwistyce edukacyjnej, a także $w$ teoriach społecznych i koncepcjach o charakterze interdyscyplinarnym - w teorii działania komunikacyjnego Jürgena Habermasa, teorii Ernesto Laclau, Michela Foucaulta, w nurtach krytycznej analizy dyskursu Ruth Wodak, Normana Fairclougha, Jamesa Paula Gee’a i w badaniach etnograficznych. Występują również próby łączenia dość odległych podejść teoretycznych, na przykład lingwistycznych i etnograficznych, bez charakterystycznej jednak dla tego drugiego nurtu analizy procesualności dyskursu i interakcji.

Uzyskane rezultaty analizy publikacji naukowych z kategorią dyskursu edukacyjnego w tytule nie opisują oczywiście pełnego spektrum istniejących praktyk badawczych, lecz, co warte podkreślenia, takie elementy tekstu jak tytuł publikacji, abstrakt i słowa kluczowe spełniają w komunikacji naukowej szczególną funkcję. Tytułom przypisywany jest status metatekstu, tekstu o tekście, inicjalnego elementu całego komunikatu (Wojtak, 2006). Tytuły publikacji naukowych nie pozostają więc bez istotnego wpływu na upowszechnianie się i dyskursywne konstruowanie znaczeń kategorii dyskursu edukacyjnego. 
Jak już wspomniałam wyżej, praktyka badań nad różnie skonceptualizowanym dyskursem edukacyjnym bazuje na konkretyzacji dwóch składowych: dyskursu i edukacji oraz relacji między nimi. Ta, być może mało odkrywcza, konstatacja niesie jednak istotne konsekwencje: dla refleksji nad pojęciem dyskursu edukacyjnego nie mniej ważne od definicji dyskursu są koncepcje edukacji. Na ciekawy trop, ukazujący zróżnicowane relacje pomiędzy domeną dyskursu a domeną edukacji, prowadzi analiza pól semantycznych trzech definicji leksykalnych, które wyostrzają różnice pomiędzy dyskursem edukacyjnym rozumianym jako „dyskurs o edukacji” i jako „dyskurs w edukacji”.

Leksykon Pedagogika (Milerski, Śliwerski, 2000) przedstawia trzy definicje terminu „dyskurs edukacyjny”. Pojęcie to wyjaśnione zostało jako:

- uwarunkowane historycznie i epistemologicznie reguły budowy wypowiedzi na temat edukacji;

- obecny w szkole gatunek „mowy”, będący rodzajem wyspecjalizowanej praktyki komunikatywnej, która ma swoje reguły i prawa;

- zdarzenie interakcyjne, podczas którego dochodzi do wymiany komunikatów w procesie edukacyjnym.

Każde $\mathrm{z}$ trzech wskazanych w leksykonie znaczeń tworzy zróżnicowane, ale częściowo nakładające się pola semantyczne pojęć dyskursu i edukacji. Całościowa analiza pól semantycznych obejmuje badanie pól leksykalnych skonstruowanych z siatek relacji. Siatki te są złożone z ekwiwalentów, asocjacji, opozycji, określeń, działań podmiotu i działań wobec podmiotu (Głowiński, 1980). Dla leksykalnej analizy definicji przydatne są przede wszystkim powiązania pojęciowe i tematyczne (asocjacje i opozycje), określenia oraz ekwiwalencje. Rezultaty analizy semantycznej stanowią dla mnie punkt wyjścia dla sproblematyzowania nie tylko znaczeń nadawanych kategorii dyskursu, ale przede wszystkim edukacji i jej relacji do praktyk dyskursywnych. Rozpocznę od ostatniego ujęcia, które nazywam ujęciem interakcyjnym (Ostrowicka, 2014).

\section{Dyskurs edukacyjny jako interakcja w procesie edukacyjnym}

$\mathrm{W}$ ujęciu interakcyjnym ekwiwalentem pojęcia dyskurs jest zdarzenie interakcyjne, powiązane z wymianą komunikatów. Jeśli w najogólniejszym sensie przyjmiemy, iż zdarzenie jest czymś, co należy do sfery praktyki, to pojęcie dyskursu edukacyjnego rozciąga się na obszar praktyki społecznej, w której zachodzą procesy edukacyjne. Asocjacje interakcyjne generują bogate treści semantyczne. W ramach teorii socjologicznych, począwszy od tradycji symbolicznego interakcjonizmu Georga 
H. Meada (1975) i teorii dramaturgicznej Ervinga Goffmana (2000), interakcja jest dynamiczną sekwencją "nawzajem ku sobie zwróconych działań społecznych” (Sztompka, 2002), takich jak: kłótnia, rozmowa, plotkowanie, wizyta u dyrektora czy egzamin. W definicji leksykalnej dyskurs edukacyjny nie jest jednak synonimem interakcji - ta jest pojęciem szerszym, nie każdy bowiem rodzaj zdarzenia interakcyjnego jest jednocześnie wymianą komunikatów w procesie edukacyjnym (Retter, 2003). W teoriach komunikacji komunikaty rozumiane są jako „znaczące wiadomości", których znaczenie wypływa z kontekstu sytuacyjnego (Retter, 2003). $\mathrm{W}$ interakcyjnej perspektywie poznawczej znaczenie dyskursu edukacyjnego odsyła zatem do działań podejmowanych przez użytkowników języka w określonych warunkach - $\mathrm{w}$ warunkach edukacyjnych procesów. W tym miejscu warto zauważyć, że w literaturze pedagogicznej procesy edukacyjne ujmowane są szeroko i utożsamiane zarówno z celowościowymi procesami wychowania i kształcenia, jak również z procesami uspołecznienia poprzez organizację i instytucjonalizację życia (to na przykład procesy globalizacji, etatyzacji, nacjonalizacji) oraz z procesami naturalnego wrastania jednostki w rodzinę i jej ofertę kulturową (socjalizacja pierwotna, inkulturacja) (Kwieciński, 1992; Hejnicka-Bezwińska, 2008).

W tak szeroko zinterpretowanej definicji dyskursu edukacyjnego jako interakcji w procesie edukacyjnym możemy problematyzować wszystkie warunki owej interakcji, między innymi jej uczestników (kto uczestniczy w wymianie komunikatów? z jakiej pozycji zabiera głos? w jakim celu? itd.), miejsce zdarzenia (gdzie dochodzi do wymiany komunikatów i procesu edukacyjnego?) i efektu komunikacji (jakie stany i tożsamości dyskurs edukacyjny wytwarza, jakie utrwala lub anuluje?). Co istotne dla podejmowanej tu próby uchwycenia relacji pomiędzy dyskursem a edukacją, $w$ tak rozumianym dyskursie edukacyjnym tym miejscem interakcji jest szeroko rozumiany proces edukacyjny, realizowany $\mathrm{w}$ przestrzeni publicznej i prywatnej, zinstytucjonalizowanej, formalnej, codziennej i nieformalnej. Interakcyjne ujęcie dyskursu edukacyjnego nie zawęża perspektywy badawczej do zainteresowania wyłącznie dyskursem osób profesjonalnie i instytucjonalnie związanych z kształceniem i wychowaniem, ale obejmuje także komunikaty publicystów, polityków, ekonomistów, celebrytów i innych uczestników dyskursu publicznego, którzy kształtują dyskursywne warunki procesów uspołecznienia (Ostrowicka, 2015b). Perspektywa interakcyjna zakłada zatem liczne i zróżnicowane obszary dyskursów funkcjonalnie związanych $\mathrm{z}$ edukacją: pola związane z procesami uspołecznienia, pola związane z procesami wychowania i kształcenia oraz pola związane z procesami socjalizacji pierwotnej i inkulturacji. To powiązanie ma charakter funkcjonalny, ponieważ dotyczy celów i efektów (edukacyjnych) w praktykach dyskursywnych. 


\section{Dyskurs edukacyjny jako gatunek charakterystyczny dla szkoły}

Ekwiwalentem dyskursu w ujęciu instytucjonalnym jest gatunek dookreślany w kategoriach wyspecjalizowanej praktyki komunikatywnej. Dodatkową atrybucją jest przypisanie tak rozumianemu dyskursowi edukacyjnemu swoistych reguł i praw. Asocjacje znajdujące się w polu semantycznym, wiążące dyskurs edukacyjny ze szkołą, pozwalają właśnie w tej instytucji poszukiwać cech, reguł i norm gatunkowych. Warto w tym miejscu zauważyć, że w typologiach przestrzeni dyskursywnej proponowanych przez językoznawców „dyskurs edukacyjny” najczęściej zaliczany jest do dyskursu instytucjonalnego (obok dyskursu urzędowego, medycznego, akademickiego i innych) (np. Nocoń, 2009; Witosz, Sujkowska-Sobisz, Ficek, 2016). Ten typ dyskursu (instytucjonalny) charakteryzuje specyficzna, asymetryczna relacja komunikacyjna pomiędzy tak zwanymi klientami (laikami) a ekspertami, którym przypisane są społecznie legitymizowane kompetencje. Ponadto zakłada się, że w dyskursach instytucjonalnych aktywizowane są pożądane, przypisane do danych ról społecznych zachowania językowe (Rutkowski, 2016). Ujęcie dyskursu edukacyjnego jako instytucjonalnej praktyki komunikatywnej akcentuje zatem problem niesymetrycznych relacji i eksperckiej władzy definiowania i redefiniowania sytuacji oraz pozycjonowania w roli ucznia, wychowanka, ale także w roli nauczyciela i mistrza. Wraz z rozprzestrzenianiem się pozaformalnych i nieformalnych praktyk kształceniowych potencjalne miejsca (re)produkcji dyskursu edukacyjnego jako charakterystycznego, instytucjonalnego gatunku mogą mieć niewiele wspólnego z instytucją szkoły rozumianą w sposób tradycyjny. Procesy określane mianem pedagogizacji lub edukacjonalizacji (ang. educationalization, rzadziej pedagogization, niem. Pädagogisierung) (zob. na przykład Höhne, 2003; Simons, Masschelein, 2008; Smeyers, Depaepe, 2008; Czyżewski, Marynowicz-Hetka, Woroniecka, 2013; Ostrowicka, 2015a), oparte na transmisji dyskursu edukacji instytucjonalnej do domen źródłowo niezwiązanych ze szkołą, jak biznes, polityka czy mass media, opierają się jednak na specyficznej dla niej logice: na dyskursie w relacji nauczyciel - uczeń, wychowawca - wychowanek (również w warunkach tak zwanego samokształcenia, uczenia się i samowychowania) oraz na dyskursie ewaluacji opartej na normach. Jak trafnie zauważa Lynn Fendler (2008), ocenianie według skali zgodności z przyjętym wzorcem, standardem uznanym za normalny dla określonej populacji, wieku czy poziomu kształcenia jest typową praktyką szkolnej rzeczywistości. W warunkach pedagogizacji życia społecznego mamy do czynienia z redefinicją szkoły i systemu oświaty, przedefiniowaniem roli nauczyciela i ucznia, wyjściem z przestrzeni zamknięcia do prze- 
strzeni otwartych. Szkołą staje się cała biografia człowieka, obejmująca edukację poza systemem oświaty, także $\mathrm{w}$ „organizacjach uczących się" i innych domenach życia społecznego. Jednak ujęcie dyskursu edukacyjnego w kategoriach wypowiedzi charakterystycznych dla instytucji szkoły uczula na specyficzne, asymetryczne relacje komunikacyjne i wytworzone w ich ramach gatunki wypowiedzi. Prototypowymi gatunkami (Rosch, 1987) praktyk komunikatywnych w edukacji, które funkcjonują również poza systemem oświaty, są między innymi podręcznik, wykład, lekcja szkolna i egzamin.

Podsumowując tę część, podkreślmy raz jeszcze, że instytucjonalna optyka ogniskuje uwagę na gatunkowych powiązaniach dyskursu ze sferą edukacji. Nie pokrywają się one w całości z opisanymi wyżej obszarami dyskursów funkcjonalnie związanych z procesami edukacyjnymi. Te drugie mają szerszy zakres, obejmujący również te interakcje, które nie realizują prototypowych cech dyskursu „szkolnego”. Z kolei na tematyczne powiązanie kategorii dyskursu i edukacji wskazuje trzecia słownikowa definicja dyskursu edukacyjnego.

\section{Dyskurs edukacyjny jako dyskurs o edukacji}

Zgodnie z kolejnym ujęciem leksykalnym dyskursem edukacyjnym są uwarunkowane historycznie i epistemologicznie reguły budowy wypowiedzi na temat edukacji (Milerski, Śliwerski, 2000). Ekwiwalentem dyskursu stały się w tym przypadku „reguły budowy wypowiedzi”. Rzeczone reguły są uwarunkowane historycznie i epistemologicznie, a więc zależą od wiedzy wytwarzanej i uznawanej w danym miejscu i czasie historycznym. Ta Foucaultowska, archeologiczna perspektywa (Ostrowicka, 2014) stawia w polu semantycznym jako kluczową dla interesującej nas kategorii kwestię reguł, które formują przedmiot dyskursu, jego modalność, wykorzystywane w nim pojęcia oraz strategie (Foucault, 1977: 181). Chodzi tu więc o warunki możliwości zaistnienia wypowiedzi, tkwiące w zajmowanych przez jednostki pozycjach, w miejscach, z których się wypowiadają, a także w relacjach i strukturach społecznych. Pojęcie wypowiedzi o edukacji wskazuje na tematyczny związek, wedle którego formowany jest dyskurs. Zgodność tematyczna, jakim podlegają jego elementy (przedmioty, pojęcia, modalności i strategie), pozwala na wyodrębnianie w praktyce badawczej różnych formacji dyskursywnych związanych ze sferą edukacji. Z formacją dyskursywną mamy z kolei do czynienia wówczas, gdy „zdołamy określić jakąś regularność w obrębie przedmiotów, sposobów wypowiadania, pojęć i wyborów tematycznych (porządek, korelacje, pozycje, funkcjonowanie, transformacje)" (Foucault, 1977: 64). Na tej podstawie pojęcie 
dyskursu edukacyjnego, rozumianego jako zbiór wypowiedzi, który charakteryzuje regularność formacji dyskursywnej, rozciąga się na różne warianty instytucjonalnych dyskursów tematycznie powiązanych z edukacją, tj. dyskurs urzędowy, naukowy, polityczny, ekonomiczny czy religijny o edukacji. Mowa jest o dyskursach instytucjonalnych, które mają charakter "poważnych aktów wiedzy” (Bacchi, Bonham, 2014), to znaczy takich, których znaczenie i rola wynikają z funkcjonowania w ramach społecznie podzielanej wiedzy i „prawdy” o rzeczywistości edukacyjnej.

Archeologiczna perspektywa wprowadza zatem kolejne rozszerzenie pojęcia dyskursu edukacyjnego, wskazując na tematyczny związek dyskursu i edukacji. Późniejsze, genealogiczne i etyczne prace Foucaulta dostarczają inspiracji i pojęć do konceptualnego uchwycenia owego związku. Ze względu na ograniczenia objętości artykułu w następnej sekcji przywołam tylko wybrane, w których dyskurs jako praktyka „wytwarzania podmiotów” jest praktyką edukacyjną. W takim kontekście interpretacyjnym, czyli przy założeniu obligatoryjnej atrybucji edukacyjnej dyskursu, stosowanie terminu „dyskurs edukacyjny” wytwarza semantyczny nadmiar. W związku z tym w kolejnej części porzucam pleonastyczne z tej perspektywy teoretycznej wyrażenie „dyskurs edukacyjny” na rzecz terminu „dyskurs”.

\section{Dyskurs jako prakłyka edukacyjna}

Foucaultowskie ujęcie praktyk dyskursywnych, skoncentrowane na regułach tworzenia wypowiedzi, sygnalizuje problem relacji wiedzy i dyskursu. Nacisk położony jest tutaj na wytwarzanie podmiotów i przedmiotów jako „oczywistych”. Owe dyskursywne relacje „determinują splot powiązań, jakie dyskurs musi realizować, aby móc mówić o takich czy innych przedmiotach, aby móc je wskazać, nazwać, analizować, klasyfikować, wyjaśnić itd." (Foucault, 1977: 73). Ten splot powiązań i warunków dyskursu opisuje francuski filozof za pomocą kolistej relacji wiedzy z praktyką dyskursywną:

Wiedza jest tym, o czym można mówić w danej praktyce dyskursywnej i dzięki czemu praktyka się wyodrębnia. (...) Wiedza to również przestrzeń, w której podmiot może zajmować pewne pozycje, aby mówić o przedmiotach, z jakimi ma do czynienia w swoim dyskursie (w tym sensie, wiedza medycyny klinicznej jest zespołem funkcji patrzenia, pytania, odczytywania, rejestrowania i rozstrzygania, jakie może sprawować podmiot dyskursu lekarskiego). Wiedza to również pole współistnienia i zależności wypowiedzi, na którym pojęcia zjawiają się, określają, znajdują zastosowanie i przekształcają się. (...) Wreszcie wiedzę określają możliwości zastosowania i przywłaszczenia, jakie niesie w sobie dyskurs. (...) nie ma wiedzy bez określonej praktyki dyskursywnej; zaś każda praktyka dyskursywna określa się poprzez wiedzę, jaką tworzy. (Foucault 1977: 221) 
Praktyki dyskursywne są więc praktykami formułującymi przedmioty/podmioty, o których owe dyskursy mówią. Tym samym Foucaultowska koncepcja wiedzy ukazuje ontologiczny związek dyskursu i edukacji, jeśli ta druga rozumiana będzie w kategoriach złożonej i wielokierunkowej relacji pomiędzy jednostką a szeroko rozumianymi praktykami wiedzotwórczymi. Praktyka edukacyjna to bowiem całość warunków, działań i procesów, w których formowane są tożsamości, w ich niedomkniętych, płynnych i dynamicznych formach. W refleksji pedagogicznej do określenia praktyki edukacyjnej, która ma charakter względnie spójny i trwały, wykorzystywane jest pojęcie pedagogii (zob. Szkudlarek, 1993; Kwieciński, 2004; Męczkowska, 2006; Ostrowicka, 2015b). Dzięki badaniu czasowo i przestrzenie ulokowanych praktyk dyskursywnych możliwa staje się rekonstrukcja określonych pedagogii - specyficznych, historycznie i epistemologicznie uwarunkowanych „obiektyfikacji podmiotu” (zob. Rabinow, 1984). Analogicznie do trzech trybów obiektyfikacji, wyodrębnionych przez Paula Rabinowa (1984), we współczesnej praktyce edukacyjnej wyodrębnić możemy co najmniej trzy tryby pedagogii:

1) repartycji,

2) naukowych klasyfikacji,

3) „subiektyfikacji” (subjectification).

Wzorcowym przykładem pedagogii repartycji są praktyki przestrzennego rozmieszczania i dzielenia, będące immanentną częścią dyskursów klasyfikacji i hierarchizacji społecznej. W tym procesie - wspieranym wiedzą nauk społecznych ${ }^{2}$ nadawane są społeczne i jednostkowe tożsamości oparte na wybranych kryteriach, takie jak: wiek, płeć, wykształcenie, status ekonomiczny, zdrowie, poziom wiedzy i inne. Na ich podstawie społeczeństwo dzielone jest na kategorie (dzieci, dorosłych, seniorów, chorych, zdrowych, uczniów, bezrobotnych itd.), wobec których podejmowane są specyficzne działania edukacyjne (profilaktyczne, prewencyjne, resocjalizacyjne, wychowawcze i in.) w zaprojektowanych przestrzeniach. Osobną grupę pedagogii tworzy praktyka naukowej klasyfikacji oparta na określonych koncepcjach człowieka (filozoficznych, psychologicznych, socjologicznych). Foucaultowskie badania przedstawione w pracy Stowa i rzeczy (Foucault, 2005) zwracają uwagę na trzy naukowe modele formacji podmiotów. W pierwszym człowiek kreowany jest jako istota, która pełni określone funkcje: odbiera bodźce i odpowiada na nie, ewoluuje i podporządkowuje się wymaganiom środowiska. W modelu drugim człowiek postawiony jest w sytuacji ciągłego konfliktu, „,walki” o swój

\footnotetext{
${ }^{2}$ Por. prace Foucaulta: Historia szaleństwa $w$ dobie klasycyzmu, Narodziny kliniki i Nadzorować i karać, w których filozof opisuje związki między praktykami repartycji i rozwojem nauk społecznych.
} 
interes i własne korzyści. Jest istotą o określonych potrzebach i pragnieniach, które stara się zaspokoić. W związku z tym ustanawia zbiór reguł, które z jednej strony pozwalają na ograniczenie konfliktu, z drugiej pobudzają do sytuacji konfliktowej. W modelu trzecim człowiek wytwarzany jest jako istota pozostawiająca po sobie system znaków i symboli (przedmiotów, zwyczajów, dyskursów itd.). Wszystkie te modele krzyżują się i wzajemnie uzupełniają (Foucault, 2005). Każda pedagogia jako praktyka edukacyjna zakłada, tworzy lub odtwarza określoną koncepcję człowieka i wiedzę o nim w zakresie między innymi norm rozwojowych definiujących jego stany i zachowania, reguł rozwiązywania i unikania konfliktów społecznych oraz systemów symboli i interpretacji sytuacji.

Trzecią wreszcie formą pedagogii są działania, które podmiot wykonuje sam na sobie, balansujące pomiędzy samostanowieniem a podporządkowaniem (Rabinow, 1984). Rabinow posługuje się w tym kontekście pojęciem „subiektyfikacji” (subjectification) w znaczeniu „procesu autoformacji” (Rabinow, 1984: 11). Subiektyfikacja jest w ujęciu Rabinowa trzecią formą obiektyfikacji podmiotu, w których podmiot ukazuje się jako twórca własnego życia ${ }^{3}$.

Trzy tryby formacji podmiotu roztaczają rozległą perspektywę empiryczną i teoretyczną dla badania pedagogii. Jest to optyka rozszerzająca wywiedzione z tradycji greckiej i rzymskiej pojęcie pedagogii jako sztuki wychowania i kształcenia, pojęcie obecne również w wykładach Foucaulta poświęconych hermeneutyce podmiotu (2012).

Na zakończenie tej części rozważań warto dodać, że Foucaultowska koncepcja dyskursu stała się podstawą dla wielu rozwijanych dzisiaj intensywnie i w szczegółach dość zróżnicowanych stanowisk teoretycznych w analizie dyskursu. Poza bezpośrednią kontynuacją idei Foucaulta, która zyskała już miano badań postfoucaultowskich (zob. na przykład Bührmann i in., 2007; Ostrowicka, 2016; Nowicka-Franczak, 2017), wymienię kilka, które łączy założenie o współzależności aktorów (agency) i nadrzędnych struktur, które zarazem ograniczają i umożliwiają działanie. Są to: krytyczna analiza dyskursu (Critical Discourse Analysis), argumentacyjna analiza dyskursu (Argumentative Discourse Analysis - ADA), dyskursywny instytucjonalizm (Discursive Institutionalism - DI) oraz analiza dyskursu w socjologii wiedzy (Sociology of Knowledge Approach to Discourse - SKAD) (Leipold, Winkel, 2013). Podejścia te różnią się w zakresie szczegółowej koncepcji dyskur-

\footnotetext{
3 Warto w tym miejscu zauważyć, że Nikolas Rose posługuje się terminem „subiektyfikacja” $\mathrm{w}$ szerokim znaczeniu, to jest $\mathrm{w}$ odniesieniu do wszelkich form assujettissement. W polskim przekładzie francuskie assujettissement tłumaczone jest przez Tadeusza Komendanta jako ujarzmienie. Śladem propozycji Rose’a pojawiła się także spolszczona wersja angielskiego subjectification - subiektyfikacja (zob. Czyżewski, Marynowicz-Hetka, Woroniecka, 2013).
} 
sywnej agencji (sprawstwa), głównej osi analizy, a także proponowanych metod badania pozycjonowania podmiotów i wytwarzania tożsamości (zob. Leipold, Winkel, 2013; Ostrowicka, 2015b).

Podsumowując przedstawione wyżej cztery perspektywy poznawcze, w tak zarysowanej konstelacji związków dyskursu i edukacji można wyodrębnić powiązania funkcjonalne, gatunkowe, tematyczne i ontologiczne. Zróżnicowany charakter owych związków wyrażany jest w rozległym polu semantycznym, uwypuklającym pluralizm ekwiwalentów pojęcia „dyskurs edukacyjny”. Ich konstelację w postaci graficznej przedstawia rycina 1 .

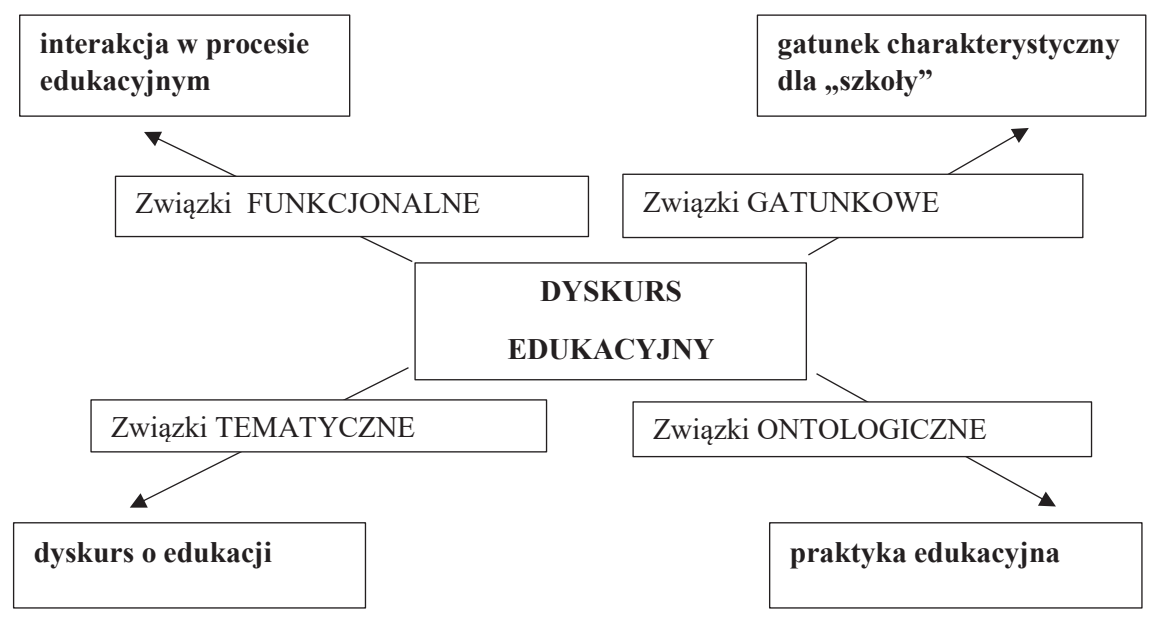

Ryc. 1. Związki dyskursu i edukacji w pojęciu dyskursu edukacyjnego

Źródło: opracowanie własne

W następnej części artykułu, pozostając w orbicie prac Foucaulta, ukażę aleturgiczną perspektywę analizy praktyk dyskursywnych. Dostarcza ona dla empirycznych badań dyskursu konkretnych narzędzi pozwalających zmierzyć się z problemem pedagogii jako reżimu prawdy, w który wpisane są, przyjmujące postać różnych modalności władzy, relacje podmiotu do „aktów prawdy”.

\section{Weredykcja, pedagogie i badania dyskursu}

Punktem wyjścia do dalszych rozważań czynię założenie, iż edukacja jest złożoną i niejednoznaczną relacją pomiędzy jednostką a szeroko rozumianymi praktykami wiedzotwórczymi. Przez te ostatnie należy rozumieć wszelkie „akty prawdy” i pro- 
cesy dyscyplinowania wiedzy oraz „reżimy prawdy”, obecne i wytwarzane również w pedagogiach. Oznacza to przyjęcie twierdzenia o ontologicznym związku dyskursu i praktyki edukacyjnej. Założenie to jest, moim zdaniem, obecne w całym pisarstwie Foucaulta - zarówno w fazie określanej mianem archeologicznej, poprzez genealogiczną, aż po prace odsyłające do problematyki autoformacji podmiotu i „estetyki egzystencji”. Pedagogie stanowiące ogół warunków (pojęcia, teorie, strategie, działania) formujących podmioty, konstytuujących ich tożsamości, są zbiorem praktyk dyskursywnych, których edukacyjny efekt jest pochodną "gier zależności” na trzech poziomach: intra-, inter- i ekstradyskursywnych. Chodzi tu o relacje pomiędzy przedmiotami, pojęciami, strategiami i działaniami w ramach pojedynczej pedagogii, o zależności pomiędzy różnymi pedagogiami, aż wreszcie o korelacje między przemianami praktyk edukacyjnych a całością zmian ekonomicznych, politycznych czy kulturowych (por. Foucault, 2016).

Konceptualizacja badań nad tak rozumianymi pedagogiami, angażująca pojęcia wywiedzione z pism Foucaulta, może przyjąć rozmaite formy. W niniejszym szkicu chciałabym zasygnalizować niektóre z możliwości, jakie wypływają z lektury wykładów francuskiego filozofa pt. Rządzenie żywymi. Uwagę skupię przede wszystkim na dwóch kategoriach: na aleturgii i wyznaniu, ukazując ich nośność jako narzędzi analizy dyskursu. Pojęcia, o których mowa, wypracował Foucault w ramach badań na relacjami między wypowiadaniem prawdy, czyli „aktami prawdy", a rządzeniem sobą i innymi. Poza wykładami z 1980 roku idee te pojawiają się już we wcześniejszych kursach poświęconych problematyce rządzenia i urządzania, a także w Historii seksualności (1995), zwłaszcza w jej tomie pierwszym o wymownym tytule Wola wiedzy.

Kategorie, które uczyniłam podstawą prowadzonych tu rozważań, pochodzą z badań Foucaulta nad historią praktyk aleturgicznych, skoncentrowanych na szczegółowej analizie Króla Edypa Sofoklesa. We wspomnianych wykładach francuski filozof nie jest zainteresowany czysto użyteczną funkcją prawdy. Potrzeba wiedzy dla rządzenia sobą i innymi jest jego zdaniem oczywista. Tworzeniu wiedzy towarzyszą akty ujawniania prawdy, które nie dają się sprowadzić do ich użyteczności w sensie instrumentalnym. Chodzi o coś więcej, jak mówi Foucault, o pewien naddatek. Do jego ukazania wykorzystuje stare greckie słowo, użyty pierwotnie przez Heraklidesa termin aleturgia (alethourgia).

Jak to ujmuje Foucault: „W grę wchodzi tu pewien zespół procedur, werbalnych bądź nie, za pomocą których ujawnia się - już to przed samym suwerenem lub jego doradcami, już to dla świadomości publicznej - coś, co określa się albo raczej ustanawia jako prawdę” (Foucault, 2014: 27). Aleturgia, czyli „rytualne i całościowe sformułowanie prawdy" (Foucault, 2014: 54) dokonuje się dwa razy - na poziomie 
„prawdy bogów” i „prawdy świadków”. Chodzi mianowicie o dwa dopełniające się typy aleturgii (weredykcji, manifestacji prawdy): aleturgię wyroczni (boską) i aleturgię świadectwa (niewolniczą). Foucault dokonuje drobiazgowej analizy obecnych w greckiej tragedii praktyk manifestacji prawdy, z których szczególna rola przypada figurom „wyroczni” i „świadka”. Ich specyfikę pozwala uchwycić porównanie wzorów procedur wydobywania prawdy, modalności wiedzy i orientacji temporalnej, co zostało przeze mnie schematycznie przedstawione w tabeli 1.

Tabela 1. Typy aleturgii - różnice w procedurach wydobywania prawdy, modalności wiedzy i orientacji temporalnej. Źródło: opracowanie własne na podstawie: Foucault, 2014

\begin{tabular}{|l|l|}
\hline \multicolumn{1}{|c|}{ Aleturgia wyroczni (boska) } & \multicolumn{1}{c|}{ Aleturgia świadectwa (niewolnicza) } \\
\hline $\begin{array}{l}\text { Procedura oparta na logice konsultacji. } \\
\text { Prawda spojrzenia w sile stwórcy, jedność } \\
\text { patrzenia i mówienia, spojrzenia } \\
\begin{array}{c}\text { i dyskursu. } \\
\text { Połączenie chwili obecnej z przyszłością } \\
\text { (nakazy, zakazy, zapowiedzi). }\end{array}\end{array}$ & $\begin{array}{l}\text { Procedura oparta na logice przesłuchania. } \\
\text { Prawda spojrzenia w tożsamości świadka. } \\
\text { Połączenie teraźniejszości z przeszłością } \\
\text { (wspomnienia, wyznania). }\end{array}$ \\
\hline
\end{tabular}

Po pierwsze, różnica pomiędzy aleturgią proroczą i aleturgią świadka wynika z mechanizmu wydobywania prawdy. Obydwie procedury głoszenia prawdy są odpowiedzią na zapotrzebowanie wiedzy, na mniej lub bardziej bezpośrednie oczekiwanie odpowiedzi, wyjaśnień, relacji. W przypadku aleturgii wyroczni, niezależnie od tego, czy odpowiedź jest pełna i jasna, trzeba ją zaakceptować. Mechanizm ten przypomina konsultacje. Natomiast relację pomiędzy pytaniem a odpowiedzią, czyli procedurą wydobywania prawdy, w przypadku aleturgii świadectwa najlepiej wyraża termin „przesłuchanie”. Te różne formy aleturgii działają na podstawie różnych strategii argumentacyjnych i legitymizacji wiedzy.

Po drugie, istotne są różnice w modalności wiedzy bogów, proroków i wiedzy świadków, niewolników. Co prawda, obie formy są sposobami „łączenia spojrzenia i dyskursu, łączenia widzenia z mówieniem"4 (Foucault, 2014: 56), ale dwoma różnymi sposobami. Wiedza boska jest zawsze weredyczna, ponieważ oświetla to, co można zobaczyć, i wypowiada to, co sprawia. W przypadku aleturgii niewolniczej widzenie i mówienie łączą się w inny sposób - poprzez rolę świadka, widza. Prawda spojrzenia tkwi tutaj w ich obecności, w tym, że byli, widzieli, zrobili. Relacja spojrzenia i dyskursu jest zakorzeniona w tożsamości świadka, w fakcie własnego doświadczenia, które pozwala mu na głoszenie prawdy.

\footnotetext{
4 Foucault wraca tutaj do kategorii „widzenia” i „mówienia” rozwijanych w Archeologii wiedzy.
} 
Po trzecie, różnica pomiędzy weredykcją bogów i niewolników wynika z dwóch poprzednich i dotyczy czasu. Prawda wygłaszana przez wyrocznię łączy chwilę obecną z przyszłością, nie dotyczy przeszłości. Aleturgia bogów, przybierając postać nakazu, wskazuje na przykład środki zaradcze, które należy podjąć, a także zapowiada to, co ma się wydarzyć. Z kolei weredykcja świadectwa ulokowana jest na osi teraźniejszość - przeszłość. To stwierdzenia, że coś się zdarzyło, podnoszone w akcie wspomnienia. Aleturgia niewolników jest zaświadczeniem prawdy na mocy wyznania i prawa pamięci (Foucault, 2014).

Rytuały produkcji prawdy, które odnajduje Foucault w kulturze hellenistycznej i chrześcijańskiej, rozwinęły się we współczesnych relacjach społecznych i instytucjonalnych. Jednak, przenosząc idee Foucaulta na grunt obecnych praktyk dyskursywnych, nie należy aleturgii proroczej i świadectwa utożsamiać z określonymi aktorami społecznymi czy instytucjami. Analiza źródłowa pozwala natomiast na uchwycenie różnic i dopełniających się mechanizmów weredykcji, które dochodzą do głosu we współczesnych pedagogiach. Badanie pedagogii z perspektywy praktyk aleturgicznych będzie zatem obejmowało co najmniej trzy aspekty:

- sposoby „naświetlania” problemów, czynienia ich widzialnymi;

- dyskursywne strategie argumentacji i uzasadniania wiedzy;

- zalecenia, nakazy, rady w sprawie przyszłości oraz diagnozy i interpretacje przeszłości.

Rola podmiotu w procedurach aleturgicznych jest potrójna - może wystąpić jako sprawca (wykonawca), dzięki któremu prawda wychodzi na jaw, jako widz (świadek) spełniania aktu prawdy oraz jako sam przedmiot aleturgii, gdy wypowiadana jest prawda o nim. Najczystszą formą ostatniego przypadku jest wyznanie, będące jednocześnie wyrazem pełnego aktu prawdy, w którym podmiot jest sprawcą aleturgii, jej świadkiem i przedmiotem (Foucault, 2014). Zobowiązanie do wypowiadania prawdy określa Foucault wymownym terminem „reżim prawdy” (Foucault, 2014). To powiązanie terminu „reżim” z aktami ujawniania prawdy ma podkreślić zasadę obligowania i konieczności, konotowaną przez pojęcie reżimu. Tym, co staje się istotne, jest zatem zobowiązanie jednostki do poddania się określonym procedurom i instytucjom władzy (w reżimie politycznym byłby to suweren, w reżimie prawnym - prawo) (Foucault, 2014). W związku z tym Foucault proponuje przeniesienie pojęcia reżimu również na teren epistemologii i prawdy, by ukazać problem zobowiązania do prawdy w określonych aktach wyznania. W tej perspektywie na mocy „reżimu prawdy” człowiek przyjmuje, po pierwsze, zobowiązanie do ujawniania prawdy, po drugie - status przedmiotu wiedzy. 
Edukacja jest praktyką aleturgiczną w podwójnym sensie. W znaczeniu ogólnym - dlatego że poprzez instytucje i aktorów w nią zaangażowanych, poprzez role im przypisywane pozwala dostrzec w określonym świetle to, co ma stanowić prawdę. W znaczeniu bardziej technicznym jest po prostu sposobem ujawniania i konstruowania wiedzy, ukazuje, w jaki sposób prawda wychodzi na jaw, dochodzi do efektu „rozpoznania”. Owa „mechanika rozpoznania” jest, z jednej strony, procesem cyrkulacji od podmiotu do przedmiotu prawdy, gdy w efekcie oceny to rozpoznający zostaje trafiony strzałą, którą sam wypuścił; z drugiej strony, jest techniką, procedurą i pewnym rytuałem, za sprawą którego dochodzi do manifestacji prawdy (por. Foucault, 2014).

Dzięki badaniu pedagogii przez pryzmat mechanizmów aleturgicznych możemy:

- rozpoznawać topografię dyskursów o edukacji/w edukacji i dominujące mapy teoretyczne, które naświetlają wybrane punkty terenu i relacje między nimi;

- identyfikować warunki aktów „prawdy” edukacyjnej: sprawców, świadków i przedmioty wiedzy;

- rekonstruować modalności, orientację temporalną i status dyskursów uruchamianych w zróżnicowanych kontekstach historycznych, politycznych i kulturowych.

Nauczanie i wytwarzanie wiedzy naukowej są w analizach Foucaulta „wzorcowymi” przykładami reżimów prawdy. Zainteresowanie relacjami pomiędzy procedurami ujawniania prawdy a podmiotami, które dokonują owych aktów, a także pomiędzy podmiotami będącymi ich świadkami lub przedmiotami zakreśla rozległe pole badań nad praktykami edukacyjnymi. Badania te obejmują odpowiedzi na pytania o to, w jaki sposób wyznawana jest prawda, wobec kogo i co jest jej przedmiotem. Problem dyskursywnego wytwarzania wiedzy w relacji z „innym” jest szczególnie wyeksponowany w pojęciu wyznania, które zakłada tożsamość podmiotu i przedmiotu wypowiedzi (por. Foucault, 2014). Wyznanie jako kategoria analizy praktyki dyskursywnej uwzględnia badanie warunków możliwości, przebiegu i efektów wypowiadania "prawdy” o sobie przed „innym”. „Inny”, przed którym składane jest zeznanie, nie musi być jednostką psychofizyczną - to każda forma publiczności, również tej rozproszonej i wirtualnej, która wyznania się domaga (Ostrowicka, 2015c). Badanie pedagogii wyznania jako jednej z ,technik siebie" koncentruje się na technicznych aspektach tej praktyki edukacyjnej, a szczegółowe kategorie analityczne dotyczą:

- technik indywidualizacji podmiotu/przedmiotu wypowiedzi, w tym także sposobów unifikacji i uniformizacji „podmiotu mówiącego" i tematu wyznania; 
- technik dzielenia i dyferencjacji, czyli sposobów i kryteriów różnicowania podmiotu mówiącego i podmiotu przyjmującego zeznanie;

- technik patrzenia, „wkraczania z oceną”, postaci, działań i funkcji „Innego”;

- „kanałów komunikacyjnych”, mediów i materialnych „śladów” wyznania (por. Gutman, 1988; Ostrowicka, 2015c).

Kończąc tę część rozważań, warto podkreślić, że potencjał analityczny kategorii aleturgii, reżimów prawdy i wyznania nie jest ograniczony do badań w perspektywie ontologicznej relacji pedagogii i praktyki dyskursywnej. Konstelacyjny charakter omówionych w części pierwszej związków dyskursu i edukacji uwypukla wzajemne przenikanie się pól semantycznych pojęcia dyskursu edukacyjnego. A to oznacza również możliwość akcentowania rozmaitych aspektów praktyk aleturgicznych w zależności od zainteresowania funkcjonalnym, gatunkowym czy też tematycznym związkiem domen dyskursu i edukacji. Przykładów badań empirycznych w tym zakresie dostarcza zbiór pod redakcją Andreasa Fejesa i Katherine Nicoll pod tytułem Foucault and a Politics of Confession in Education (2015).

\section{Podsumowanie}

Podstawowym celem artykułu uczyniłam próbę typologizacji związków pomiędzy dziedzinami dyskursu i edukacji, dających się zrekonstruować na podstawie analizy pól semantycznych wieloznacznego pojęcia „dyskurs edukacyjny”. Podjęte tu poszukiwania zrodziła potrzeba zaakcentowania teoretycznej nieoczywistości kategorii edukacji, a tym samym jej związków z dyskursem. O ile w badaniach nad dyskursem edukacyjnym pojęcie dyskursu jest traktowane z teoretyczną uwagą i problematyzowane w kontekście różnych ujęć filozoficznych, o tyle problem teorii edukacji bywa marginalizowany. Przedstawione tu rezultaty analiz, uwzględniające dwa rodzaje źródeł (badania empiryczne oraz leksykon współczesnej pedagogiki), wyostrzają zasadność dyskursywnego uwrażliwienia na niejednorodne pola semantyczne pojęcia dyskursu edukacyjnego. W praktyce badawczej termin ten oznacza „dyskurs o edukacji”, „dyskurs w edukacji” lub „dyskurs jako edukacja”. Niezwykle szeroki zakres zjawisk objętych wymienionymi kategoriami jest pochodną bogactwa zarówno teorii dyskursu, jak i koncepcji edukacji. W rezultacie możemy mówić o swoistej konstelacji powiązań pomiędzy interesującymi nas dziedzinami: związków funkcjonalnych, tematycznych, gatunkowych i ontologicznych. Założenie ontologicznego związku obu domen skłania do większej ostrożności i precyzji w posługiwaniu się terminem „dyskurs edukacyjny”. Jeśli przyjmiemy teoretyczne założenie, iż 
dyskurs ex definitione jest praktyką wiedzotwórczą, staje się on kategorią bliskoznaczną pedagogii w znaczeniu zbioru relacji pomiędzy pojęciami, teoriami, rzeczami i działaniami, zaangażowanymi w formowanie (się) podmiotów. Poprzez zastosowanie analogii jako zasady metodologicznej owe edukacyjne efekty, konstruowanie tożsamości, pedagogie dają się opisać i wyjaśniać w optyce Foucaultowskich „gier zależności” na poziomach: intradyskursywnym (w ramach pojedynczej pedagogii), interdyskursywnym (pomiędzy pedagogiami) i ekstradyskursywnych (między praktykami edukacyjnymi a całością przemian ekonomicznych, politycznych czy kulturowych). Analogia rozumiana jako relacja podobieństwa pomiędzy regułami formacyjnymi dyskursu a warunkami edukacyjnymi pozwala na wnioskowanie o pedagogiach na podstawie analizy dyskursu. Konceptualizacja badań nad tak ujętą praktyką edukacyjną może oczywiście przyjąć rozmaitą postać. Przedmiotem mojego zainteresowania w drugiej części artykułu uczyniłam kategorie wywiedzione z hellenistycznej i chrześcijańskiej tradycji: pojęcie aleturgii i wyznania, podejmując próbę ukazania ich analitycznego potencjału dla badań nad współczesnymi pedagogiami.

\section{Literatura}

Bacchi C., Bonham J. (2014). Reclaiming Discursive Practices as an Analytic Focus: Political Implications. „Foucault Studies” 17.

Bührmann A.D., Diaz-Bone R., Gutiérrez Rodriguez E., Kendall G., Schneider W., Tirado F.J. (eds.) (2007). "Forum Qualitative Sozialforschung: From Michel Foucault's Theory of Discourse to Empirical Discourse Research" 8(2).

Czyżewski M., Marynowicz-Hetka E., Woroniecka G. (red.). (2013). Pedagogizacja życia społecznego. „Societas/Communitas" 2.

Fejes A., Nicoll K. (eds.). (2015). Foucault and a Politics of Confession in Education. London.

Fendler L. (2008). Educationalising trends in societies of control: assessments, problem-based learning and empowerment. [W:] P. Smeyers, M. Depaepe (eds.). Educational Research: The Educationalization of Social Problems. "Educational Research" 3, DOI 10.1007/978-1-4020-9724-9 1.

Foucault M. (1977). Archeologia wiedzy. Przeł. A. Siemek. Warszawa.

Foucault M. (1995). Historia seksualności. Przeł. B. Banasiak, T. Komendant, K. Matuszewski. Warszawa.

Foucault M. (2012). Hermeneutyka podmiotu. Wykłady w Collège de France 1981-1982. Przeł. M. Herer. Warszawa.

Foucault M. (2014). Rządzenie żywym. Wykłady w Collège de France 1979-1980, przeł. M. Herer. Warszawa.

Foucault M. (2016). Odpowiedź na pytanie. Przeł. Aleksandra Charędziak. „Praktyka Teoretyczna” 4 (22). DOI: $10.14746 /$ prt.2016.4.3.

Głowiński M. (red.) (1980). Język i społeczeństwo. Warszawa. 
Gutman H. (1988). Rousseau's confessions: A technology of the self. [W:] L. Martin, H. Gutman (eds.). Technologies of the Self. London.

Hejnicka-Bezwińska T. (2008). Pedagogika ogólna. Podręcznik akademicki. Warszawa,

Howarth D. (2008). Dyskurs. Przeł. A. Gąsior-Niemiec. Warszawa.

Höhne T. (2003). Pädagogik der Wissengesellschaft. Bielefeld.

Koszyk M., Machowska J. (1996). Profilowanie pojęć w dyskursie edukacyjnym o tematyce religijnej.

[W:] T. Rittel (red.). Dyskurs edukacyjny. Kraków.

Kwieciński, Z. (1992). Socjopatologia edukacji. Warszawa.

Kwieciński Z. (2004). Problem pedagogii nurtów głównych i pobocznych. „Teraźniejszość - Człowiek - Edukacja” 3.

Leipold S., Winkel G. (2013). Discursive Agency: Towards an actor-centered analysis of political discourses. Referat przedstawiony na 1. International Conference on Public Policy (ICPP 2013). Grenoble, France.

Mead G.H. (1975). Umysł, osobowość i społeczeństwo. Przeł. Z. Wolińska. Warszawa.

Męczkowska A. (2006). Podmiot i pedagogika. Od oświeceniowej utopii ku pokrytycznej dekonstrukcji. Wrocław.

Milerski B., Śliwerski B. (red.). (2000). Pedagogika. Leksykon. Warszawa.

Milewski S. (1996). „Język nianiek” jako specyficzny rodzaj dyskursu edukacyjnego. [W:] T. Rittel (red.). Dyskurs edukacyjny. Kraków.

Nasalska E. (2004). Polsko-niemieckie dyskursy edukacyjne: lata 1949-1999. Warszawa.

Nocoń J. (2009). Podręcznik szkolny w dyskursie dydaktycznym - tradycja i zmiana. Opole.

Nowak-Dziemianowicz M. (2011). Pedagogika dyskursywna: nadzieje i możliwości. [W:] M. Nowak-Dziemianowicz, P. Rudnicki (red.). Pedagogika: zakorzenienie i transgresja. Wrocław.

Nowicka-Franczak M. (2017). Niechciana debata. Spór o książki Jana Tomasza Grossa. Warszawa.

Ostrowicka H. (2014). Kategoria dyskursu w języku $i$ w badaniach edukacyjnych - w poszukiwaniu osobliwości pedagogicznie zorientowanej analizy dyskursu. „Forum Oświatowe” 2 (32).

Ostrowicka H. (2015a). O badaniach „pedagogizacji życia społecznego” kilka słów z poznawczej perspektywy pedagogiki ogólnej. „Nauki o Wychowaniu. Studia Interdyscyplinarne” 1.

Ostrowicka H. (2015b). Przemyśleć z Michelem Foucaultem edukacyjne dyskursy o młodzieży. Dyspozytyw i urządzanie. Kraków.

Ostrowicka H. (2015c). Wyznania Rousseau i dyskurs edukacyjny - zarys badań w perspektywie (post) foucaultowskiej. „Problemy Wczesnej Edukacji” nr 2.

Ostrowicka H. (2016). Wokót problematyki „metody” w postfoucaultowskich badaniach społecznych pomiędzy strategią transkrypcji a strategią fugi. „Przegląd Socjologii Jakościowej” 12 (1).

Ożdżyński J. (1996). Niektóre cechy dyskursu edukacyjnego (na przykładzie wypowiedzi wykładowej). [W:] T. Rittel (red.). Dyskurs edukacyjny. Kraków.

Popow M. (2015a). Globalna Północ i Globalne Południe w dyskursie edukacyjnym. Krytyczna analiza treści podręczników szkolnych. „Studia Edukacyjne” t. 35.

Popow M. (2015b). Kategoria narodu w dyskursie edukacyjnym. Analiza procesów konstruowania tożsamości w podręcznikach szkolnych. Poznań.

Rabinow P. (1984). The Foucault Reader. New York.

Retter H. (2003). Komunikacja codzienna w pedagogice. Gdańsk.

Rosch E. (1987). Principles of categorization. [W:] E. Rosch, B. Lloyd (eds.) Cognition and Categorization. Hillsdale. 
Rutkowski M. (2016). Dyskurs urzędowy w ramach dyskursu instytucjonalnego. [W:] B. Witosz, K. Sujkowska-Sobisz, E. Ficek (red.). Dyskurs i jego odmiany. Katowice.

Rypel A. (2012). Ideologiczny wymiar dyskursu edukacyjnego na przykładzie podręczników języka polskiego z lat 1918-2010. Bydgoszcz.

Seredyńska D. (2013). Dyskursy edukacyjne o starości w naukach humanistycznych i społecznych: analiza konferencji ogólnopolskich. Bydgoszcz.

Simons M., Masschelein J. (2008). The governmentalization of learning and the assemblage of a learning apparatus. "Educational Theory' 58 (4).

Smeyers P., Depaepe M. (eds.). (2008). Educational research: The educationalization of social problems. "Educational Research" 3, DOI 10.1007/978-1-4020-9724-9 1.

Szczepankowska I. (2016). Konstelacja dyskursów związanych tematycznie i funkcjonalnie ze sfera prawa - próba typologii. [W:] B. Witosz, K. Sujkowska-Sobisz, E. Ficek (red.). Dyskurs i jego odmiany. Katowice.

Szkudlarek T. (1993). Wiedza i wolność w pedagogice amerykańskiego postmodernizmu. Kraków.

Sztompka P. (2002). Socjologia: analiza społeczeństwa. Kraków.

Witosz В. (2005). O ponadgatunkowych kategoriach typologicznych uniwersum mowy. „Стиль” vol. 5.

Witosz K., Sujkowska-Sobisz K., Ficek E. (red.) (2016). Dyskurs i jego odmiany. Katowice.

Wojtak M. (2006). Analiza gatunków prasowych: zręby teorii i elementy praktyki. „Media, Kultura, Społeczeństwo" 1.

Żydek-Bednarczuk U., Zeler B. (1996). Strategia i komunikacja w dyskursie edukacyjnym. [W:] T. Rittel (red.). Dyskurs edukacyjny. Kraków. 